\title{
Compatibility studies of nateglinide with excipients in immediate release tablets
}

\author{
NIHAR RANJAN PANI ${ }^{1 *}$ \\ LILA KANTA NATH ${ }^{2}$ \\ SUJATA ACHARYA ${ }^{3}$ \\ ${ }^{1}$ Department of Pharmaceutical \\ Technology, Gayatri College of Pharmacy \\ Sambalpur, Odisha-768200, India
}

2 Department of Pharmaceutical Sciences Dibrugarh University, Dibrugarh Assam-786004, India

3 University Department of Pharmaceutical Sciences, Utkal University, Bhubaneswar Orissa, India

Accepted May 5, 2011

\begin{abstract}
Experiments were done to assess the compatibility of nateglinide with selected excipients in the development of immediate release tablets of nateglinide by thermal and isothermal stress testing (IST) techniques. To evaluate the drug-excipient compatibility, different techniques such as differential scanning calorimetric (DSC) study, infra-red (IR) spectrophotometric study and isothermal stress testing were adopted. The results of DSC study showed that magnesium stearate exhibited some interaction with nateglinide. However, the results of IR, and IST studies showed that all the excipients used in the formula were compatible with nateglinide. Optimized formulations developed using the compatible excipients were found to be stable over 3 months of accelerated stability studies $\left(40 \pm 2{ }^{\circ} \mathrm{C}\right.$ and $75 \pm 5 \%$ RH). Overall, compatibility of excipients with nateglinide was successfully evaluated using a combination of thermal and IST methods and the formulations developed using the compatible excipients were found to be stable.
\end{abstract}

Keywords: nateglinide, immediate release tablet, drug-excipient interaction

Incompatibility between drugs and excipients can alter drug stability and bioavailability and thereby affect their safety and efficacy. Study of drug-excipient compatibility is an important process in the early development stage of stable solid dosage forms. However, no universally accepted protocol is available for evaluating the drug compatibility with different excipients (1). The few reported methods generally used for such studies have poor predictive values and some are laborious and time consuming. Differential scanning calorimetry (DSC) is widely used for evaluating the drug-excipient interaction (2-7). Though it has well documented advantages, such as requirement of small sample size and rapid results, exposure of drug-excipient mixture to high temperature $\left(300{ }^{\circ} \mathrm{C}\right.$ or more) may deteriorate some of the excipients used. The DSC results should be interpreted carefully, since the conclusions based on the DSC results alone can often be

*Correspondence; e-mail: niharpani@gmail.com 
misleading and inconclusive $(4,6)$. Isothermal stress testing (IST) involves storage of drug-excipient blends with or without moisture at elevated temperature $\left(>50{ }^{\circ} \mathrm{C}\right)$ for a specific period of time (normally 3-4 weeks) to accelerate drug ageing and its interaction with excipients. IST has specific application in pharmaceutical industry where the interaction between drug and excipients is visually observed and the drug content is determined quantitatively $(1,4,8,9)$. However, the disadvantage of this method is that it is time consuming and laborious. Ideally, both techniques, DSC and IST, should be used in combination during compatibility studies for the selection of excipients.

Nateglinide (NTG), a meglitinide derivative, is mainly indicated for the treatment of type-2 diabetics (10). In the present study, DSC, IR and IST were used for the selection of excipients used in the development of immediate release formulations of NTG. In recent years, despite the increasing interest in controlled release drug delivery systems, scientists are paying more attention to developing effective formulations for the poorly soluble drugs, which easily disintegrate and dissolve the active species rapidly in the GIT for better bioavailability. Bioavailability of the poorly soluble drugs from the solid oral dosage forms depends on the disintegration and dissolution of the drug substance (11).

\section{EXPERIMENTAL}

\section{Materials}

Nateglinide (purity $99.6 \%$ ), a gift sample from Glenmark Pharmaceutical Limited, India, was characterized against the working standard of NTG (purity $99.7 \%$ ), which was obtained as a gift sample from Novartis Pharmaceutical, USA. The following chemicals and excipients were purchased from commercial sources and used as such: lactose (Libraw Pharma, India), microcrystalline cellulose (Avicel PH-101, FMC, USA), croscarmellose sodium (Ac-Di-Sol, Maple Biotech, India), L-hidroxypropyl cellulose (Hyprolose, Zheijiang Joinway Pharm, China), Polacrilin K (Kyron T314, Corel Pharm, India), polyvinylpyrrolidone (Plasdone K-30, ISP, USA) and magnesium stearate (Mallinckrodt, USA).

Methanol and acetonitrile used for the preparation of mobile phase were of HPLC grade (Ranbaxy, India) and water used throughout the HPLC analysis was prepared with a water purifier (Arium, 611UF, Sartorius, Germany).

\section{Methods}

Differential scanning calorimetry. - A differential scanning calorimeter (JADE DSC, Perkin Elmer, USA) was used for thermal analysis of the drug and mixtures of drug and excipients. Excipients expected to be used in the development of immediate release tablets of NTG at an appropriate ratio were selected for the study. Individual samples of the drug and excipients as well as physical mixtures of the drug and selected excipients were weighed directly into the DSC aluminum crucible (Table I) and scanned in the temperature range of $50-300{ }^{\circ} \mathrm{C}$ under a dry nitrogen atmosphere. The heating rate was $20^{\circ} \mathrm{C}$ $\mathrm{min}^{-1}$ and the thermograms obtained were observed for interactions. 
N. R. Pani et al.: Compatibility studies of nateglinide with excipients in immediate release tablets, Acta Pharm. 61 (2011) $237-247$.

Table I. Peak temperature and enthalpy values of nateglinide in various drug-excipient mixtures

\begin{tabular}{lcccc}
\hline Sample & $\begin{array}{c}\text { Ratio } \\
\text { (drug-excipient) }\end{array}$ & $T_{\text {onset }}\left({ }^{\circ} \mathrm{C}\right)$ & $T_{\text {peak }}\left({ }^{\circ} \mathrm{C}\right)$ & $\Delta H_{\text {fcorr }}\left(\mathrm{J} \mathrm{g}^{-1}\right)^{\mathrm{a}}$ \\
\hline NTG & - & 137.21 & 144.76 & 91.0346 \\
NTG + lactose & $1: 2$ & 139.80 & 143.48 & 89.4321 \\
NTG + polacrilin K & $1: 1$ & 138.51 & 141.78 & 51.5828 \\
NTG + PVP & $1: 1$ & 137.58 & 140.38 & 31.8860 \\
NTG + talc & $3: 1$ & 139.63 & 142.81 & 40.9006 \\
NTG + Mg-stearate & $3: 1$ & - & - & - \\
\hline
\end{tabular}

${ }^{a} \Delta H_{\text {fcorr }}=\Delta H_{\text {fobs }} /$ drug conc. in sample $(\mathrm{g} / 100 \mathrm{~g})$.

IR spectroscopy. - IR spectra of the drug and a blend of drug and selected excipient were recorded on a FTIR spectrophotometer (FTIR-8400S, Shimadzu, Japan) in the range of $4000-500 \mathrm{~cm}^{-1}$ using potassium bromide discs.

Isothermal stress testing. - In the IST studies, drug and different excipients (Table II) were weighed directly into $4 \mathrm{~mL}$ glass vials $(n=2)$ and mixed on a vortex mixer for 2 $\min$. Water $(10 \%)$ was added to each of the vials and the drug-excipient blend was further mixed with a glass capillary (both ends of which were heat-sealed).

Table II. HPLC analysis of the samples under IST conditions after 3 weeks of storage

\begin{tabular}{lccc}
\hline \multirow{2}{*}{ Sample } & $\begin{array}{c}\text { Ratio } \\
\text { (drug-excipient) }\end{array}$ & \multicolumn{2}{c}{ Drug remaining $^{\mathrm{a}}(\%)$} \\
\cline { 3 - 4 } & - & $100.8 \pm 0.7$ & Control value $^{\mathrm{b}}$ \\
\hline NTG & $1: 2$ & $101.4 \pm 1.3$ & Stressed samples $^{\mathrm{c}}$ \\
NTG + lactose & $1: 1$ & $101.2 \pm 2.7$ & $100.3 \pm 1.7$ \\
NTG + polacrilin K & $2: 1$ & $101.8 \pm 1.4$ & $99.8 \pm 0.6$ \\
NTG + PVP & $3: 1$ & $100.6 \pm 2.7$ & $99.3 \pm 1.9$ \\
NTG + talc & $3: 1$ & $100.8 \pm 1.9$ & $99.3 \pm 2.0$ \\
NTG + Mg-stearate & & & $99.1 \pm 1.6$ \\
\hline
\end{tabular}

a Mean \pm standard deviation $(n=3)$.

b Drug-excipient blends without added water and stored in refrigerator ( 2 to $\left.8{ }^{\circ} \mathrm{C}\right)$.

c Drug-excipient blends with $10 \%(\mathrm{~m} / \mathrm{m})$ added water and stored at $50{ }^{\circ} \mathrm{C}$ for 3 weeks.

NTG - nateglinide, PVP - polyvinylpryrolidine.

The capillary was broken and left inside the vial to prevent any loss of material. Each vial was sealed using a teflon-lined screw cap and stored at $50{ }^{\circ} \mathrm{C}$ in air oven. The samples were periodically examined for any unusual color change. After 3 weeks of storage under the above conditions, samples were quantitatively analyzed using the in-house 
developed HPLC method. Drug-excipient blends without added water stored in a refrigerator served as controls.

For sample preparation, $2 \mathrm{~mL}$ of methanol was added into each vial. The mixture was vortexed and transferred to $100-\mathrm{mL}$ volumetric flasks. Vials were rinsed twice with methanol and the volume made up. The samples were centrifuged and the supernatant was filtered through a $0.45-\mu \mathrm{m}$ nylon membrane filter. After appropriate dilutions, samples were analyzed using HPLC and the drug content was determined from the calibration curve. A Waters 600 Pump based HPLC system equipped with Waters quaternary pump, Waters manual injector, Waters on-line degasser AF, CTO-10 AS VP column oven (at $30{ }^{\circ} \mathrm{C}$ ) and Waters $2489 \mathrm{UV} /$ Visible detector (detection at $210 \mathrm{~nm}$ ) was used. Chromatographic separation was performed on a C18 Hypersil column, with mobile phase acetonitrile/phosphate buffer $\left(\mathrm{pH} 2.5 ; 25 \mathrm{mmol} \mathrm{L}^{-1}\right)\left(35: 65, \mathrm{~V} / \mathrm{V}\right.$; flow rate $\left.1 \mathrm{~mL} \mathrm{~min}^{-1}\right)$.

Formulation development and stability study of tablets. - Details of the formulation development of the immediate release tablets of NTG are presented in Table III. In brief, tablets of nateglinide were prepared by wet granulation using a single stroke tablet punching machine (Hardik Engineering Works, India) fitted with 8-mm standard concave punches. Lactose, drug, Polacrilin K (half of the quantity from Table III) and polyvinylpyrrolidone (PVP) were passed through a sieve of $0.177 \mathrm{~mm}$ aperture and they were mixed for $20 \mathrm{~min}$ in a polyethylene bag. Granules were prepared by kneading with ethanol and were kept for air drying in a tray dryer at $45^{\circ} \mathrm{C}$. Dried granules were passed through a sieve of $0.840-\mathrm{mm}$ aperture to get uniform granules. The another half of Polacrilin K and talc were passed through a sieve of $0.177-\mathrm{mm}$ aperture and mixed with the granules for $15 \mathrm{~min}$ in a polyethylene bag. Magnesium stearate was passed through a sieve of $0.177-\mathrm{mm}$ aperture and mixed with the granules for $3 \mathrm{~min}$. Lubricated granules were compressed into tablets.

Table III. Composition of immediate release tablets of nateglinide

\begin{tabular}{lc}
\hline Ingredient & $\%(\mathrm{~m} / \mathrm{m})$ \\
\hline Nateglinide & 40.0 \\
Lactose & 48.6 \\
Polacrilin K & 4.0 \\
PVP & 3.4 \\
IPA & Qs \\
Talc & 2.3 \\
Mg-stearate & 1.7 \\
\hline
\end{tabular}

PVP - Polyvinylpyrolidine, IPA - Isopropyl alcohol

The assay of the tablets was carried out as follows. Accurately weighed tablets $(n=$ 6) were dissolved in $100 \mathrm{~mL}$ of methanol. The samples were sonicated (Ultra sonic water bath, Loba Chem, India) for $30 \mathrm{~min}$ and then filtered through a nylon membrane filter $(0.45-\mu \mathrm{m}$ pore size). The filtered solution, after appropriate dilution with methanol, was 
analyzed by a validated UV spectroscopic method (11) at $216 \mathrm{~nm}$ (UV-1601, Simadzu, Japan).

Drug release of the tablets $(n=6)$ was studied using a USP-II dissolution apparatus (TDT-06T, Electrolab, India) (12) at $50 \mathrm{rpm}$. Simulated gastric fluid, $\mathrm{pH} 1.2$ plus $0.5 \%$ sodium lauryl sulphate (SLS) $(900 \mathrm{~mL})$ maintained at $37 \pm 0.5^{\circ} \mathrm{C}$ was used as dissolution medium. The samples $(10 \mathrm{~mL})$ were withdrawn at predetermined time points $(5,10,20$, 30,45 and $60 \mathrm{~min}$ ) and replaced with an equivalent amount of fresh medium. The samples were filtered through a nylon membrane filter $(0.45-\mu \mathrm{m}$ pore size $)$ and analyzed at $216 \mathrm{~nm} \lambda_{\max }$ (11). The cumulative percent drug release was plotted against time to determine the release profile.

The optimized tablets of NTG were kept in open Petri dishes and stored in a stability chamber maintained at $40 \pm 2{ }^{\circ} \mathrm{C}$ and $75 \pm 5 \% \mathrm{RH}$ (14). The samples were withdrawn periodically and subjected to the assay and dissolution study.

\section{RESULTS AND DISCUSSION}

\section{Drug-excipient compatibility test}

DSC and IR. - Selected DSC scans of drug and drug-excipient mixtures are shown in Figs. 1a-e. Thermal behavior of the pure drug, respective excipient, and the combination of drug and excipient are compared. The onset temperature of peak ( $\left.T_{\text {onset }}\right)(140.21$ $\left.{ }^{\circ} \mathrm{C}\right)$, peak transition temperature $\left(T_{\text {peak }}\right)\left(144.76{ }^{\circ} \mathrm{C}\right)$ and heat of fusion or enthalpy $\left(\Delta H_{\mathrm{f}}\right)$ (91.0346 $\mathrm{J} \mathrm{g}^{-1}$ ) of NTG in various excipient mixtures are summarized in Table I.

The DSC thermogram of NTG showed a sharp endothermic peak at $144.76{ }^{\circ} \mathrm{C}$ and peak onset at $140.21^{\circ} \mathrm{C}$. In the majority of cases, the melting endotherm of the drug ( $T_{\text {onset }}$ and $\left.T_{\text {peak }}\right)$ was well preserved with slight broadening or shifting towards the lower temperature range. It has been reported that the shape of the peaks of the DSC thermogram and enthalpy may change due to the presence of impurity in the materials used for analysis $(5,6)$. Thus, changes in the melting endotherm of the drug from 144.76 to $140.38{ }^{\circ} \mathrm{C}$ could be due to the mixing of the drug and excipients, which lower the purity of each component in the mixture and may not necessarily indicate potential incompatibility $(7,15,16)$.

The DSC thermogram of lactose showed endothermic peaks at $145.29^{\circ} \mathrm{C}$ (indicating dehydration of bound water) and $224.59{ }^{\circ} \mathrm{C}$ (melting point). Melting endothermic peak of NTG lay at $143.48^{\circ} \mathrm{C}$ in the NTG-lactose mixture suggesting that there was no interaction between lactose and NTG (Fig. 1a).

The DSC thermogram of polacrilin K showed a broad endotherm at $117.57^{\circ} \mathrm{C}$ (starting from 50.80 and ending at $162.63^{\circ} \mathrm{C}$ ), which may be attributed to the loss of adsorbed water $(6,16)$. The thermogram of NTG-polacrilin K mixture (Fig. 1b) showed an endothermic peak of NTG at $141.78^{\circ} \mathrm{C}$, indicating that NTG was compatible with polacrilin K.

In case of PVP, a broad endotherm was observed at $98.43^{\circ} \mathrm{C}$ due to loss of adsorbed moisture (Fig. 1c). The thermogram of the NTG/PVP mixture showed broadening and shifting of the NTG peak to a lower temperature $\left(140.38{ }^{\circ} \mathrm{C}\right)$. This phenomenon may be due to simple mixing of the drug with excipient, which lowered the purity of each com- 
a)

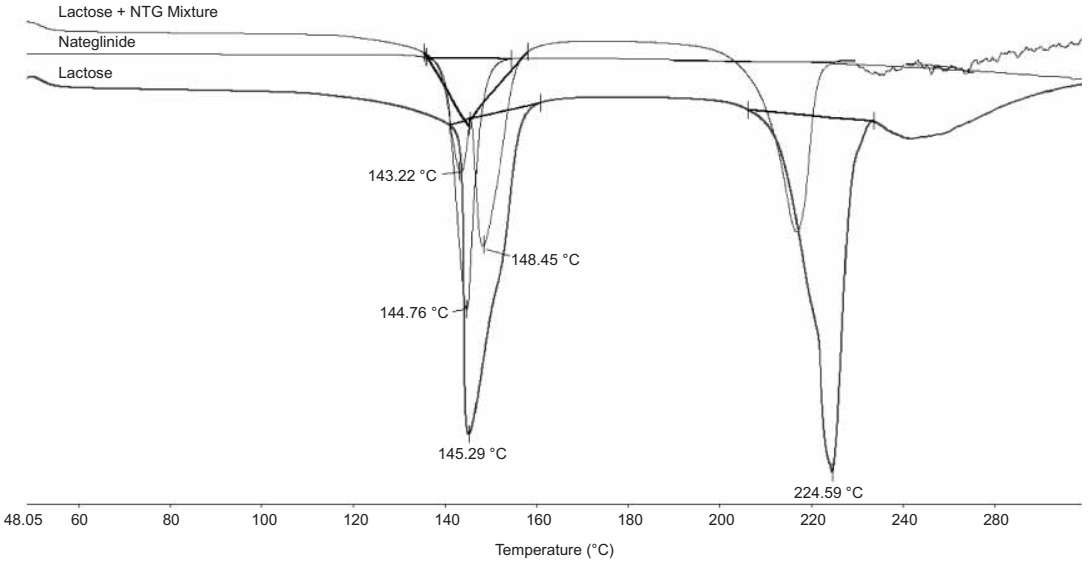

b)

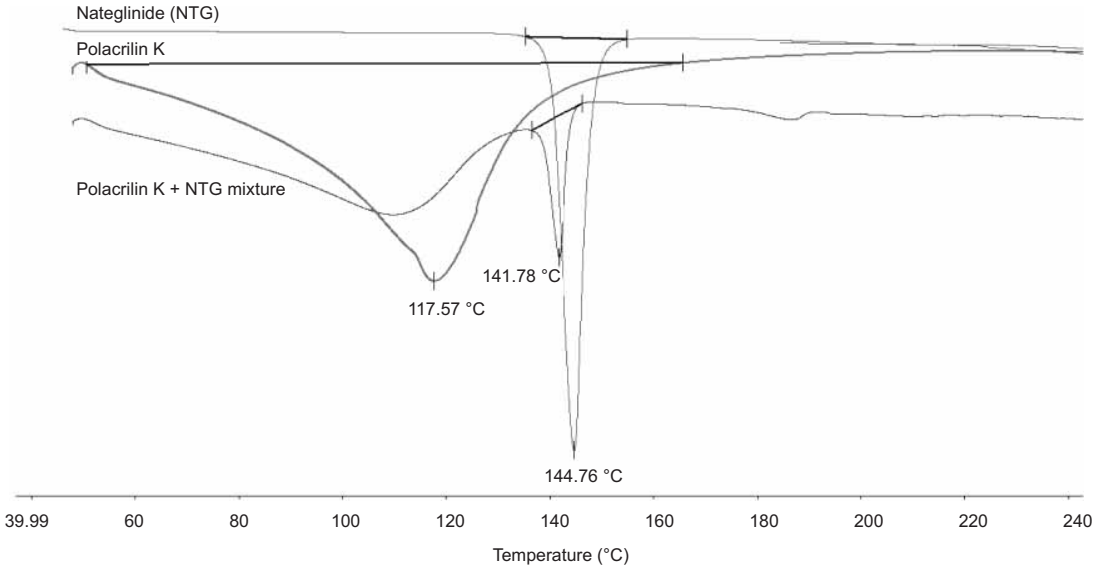

c)

Nateglinide (NTG)

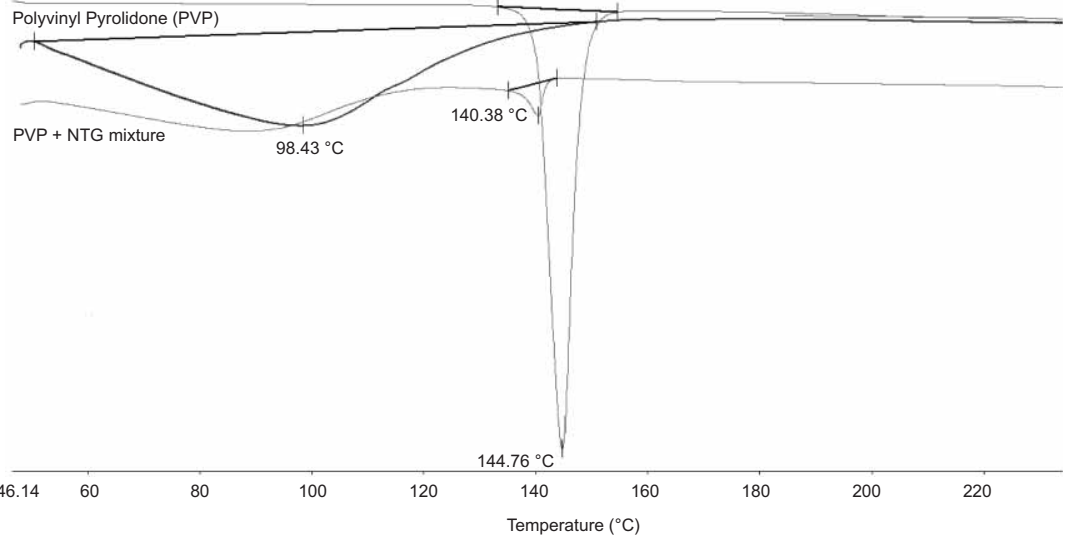

Fig. 1. DSC thermogram of nateglinide with a) lactose, b) polacrilin K, c) PVP. 
d)

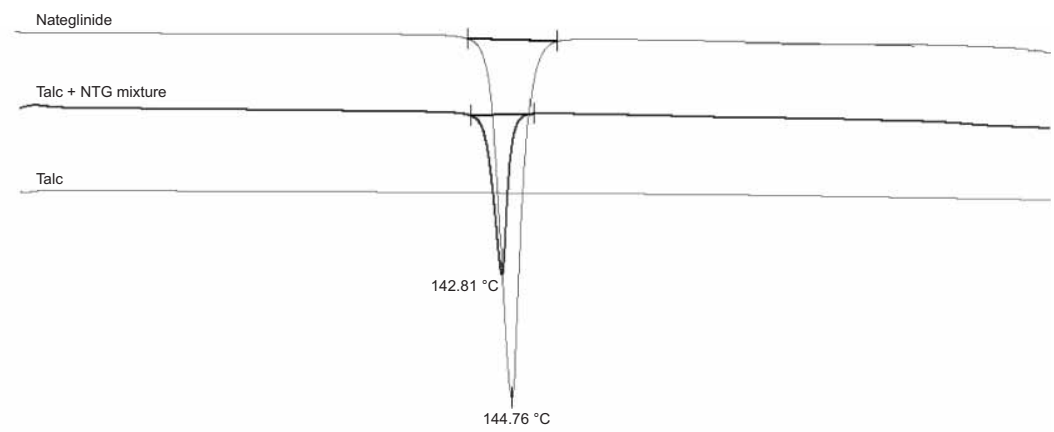

\begin{tabular}{|c|c|c|c|c|c|c|c|c|c|c|}
\hline 46.1 & 60 & 80 & 100 & 120 & 140 & 160 & 180 & 200 & 220 & 240 \\
\hline
\end{tabular}

e)

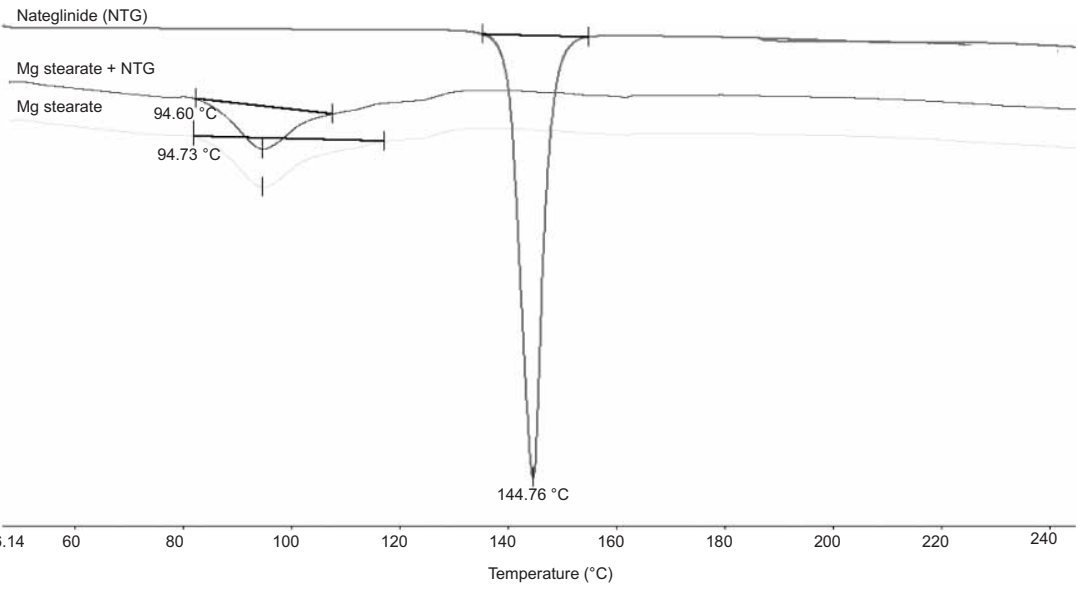

Fig. 1. Cont. DSC thermogram of nateglinide with d) talc and e) magnesium stearate.

ponent (5). This result signifies that NTG and PVP are compatible. In the DSC thermograms of talc, no peaks were observed in the range of $50-300{ }^{\circ} \mathrm{C}$ (Fig. 1d). However, the endothermic peak of NTG was well preserved at $142.81{ }^{\circ} \mathrm{C}$ in the DSC thermogram of the NTG-talc mixture. It was concluded that NTG was compatible with talc.

In the DSC thermogram of magnesium stearate, an endothermic peak was observed at $98.3^{\circ} \mathrm{C}$ with an irregular thermogram. The DSC thermogram of the NTG-magnesium stearate mixture showed disappearance of the NTG peak (Fig. 1e), which suggested that there might have been some physical incompatibility between NTG and magnesium stearate. Therefore, the NTG-magnesium stearate mixture was subjected to IR studies and its spectrum was compared with the IR spectra of NTG. Characteristic bands of NTG (Fig. 2a) were observed at $1647 \mathrm{~cm}^{-1}(-\mathrm{C}=\mathrm{O}), 1713 \mathrm{~cm}^{-1}(-\mathrm{COOH}), 2862-3096 \mathrm{~cm}^{-1}$ $\left(-\mathrm{CH}_{2}\right.$-cycloalkane) and $3296 \mathrm{~cm}^{-1}$ (-NH stretching). However, the IR spectrum of the 
a)

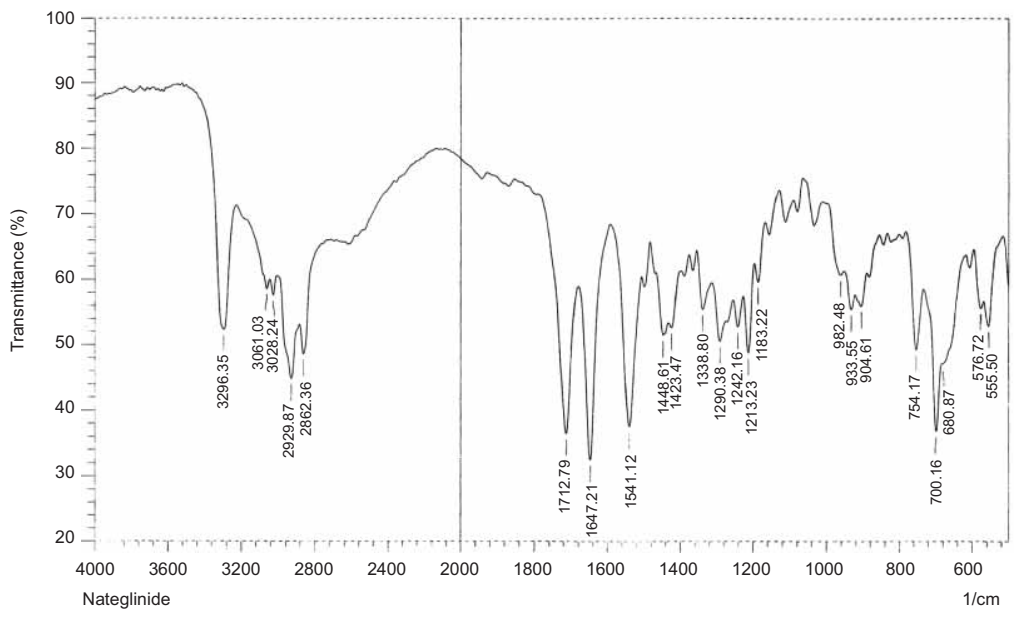

b)

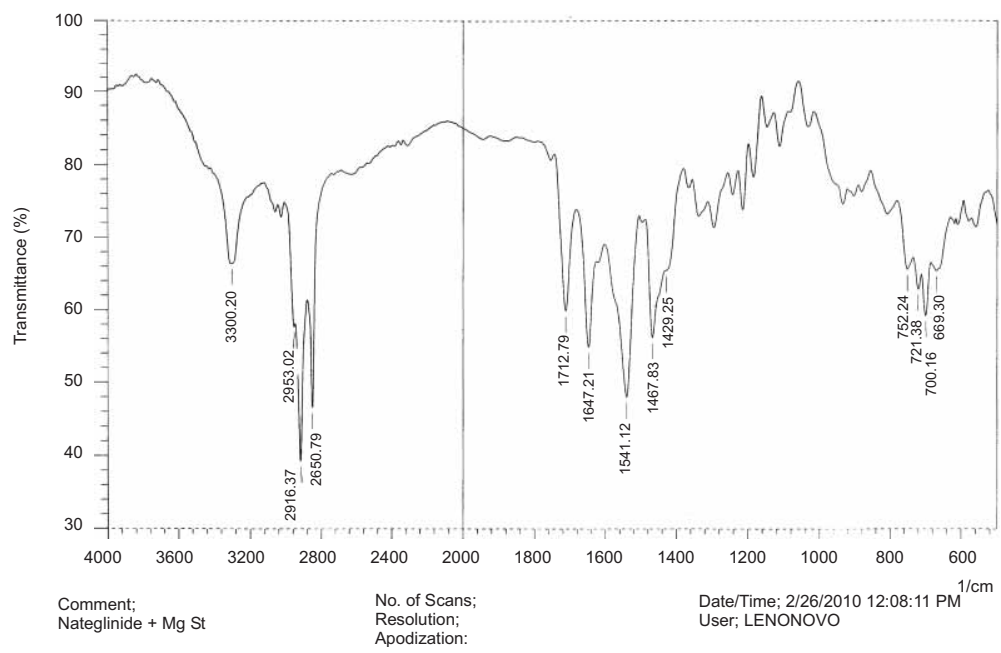

Fig. 2. Fourier transmission infra-red spectrum of a) nateglinide alone b) nateglinide with magnesium stearate.

NTG-magnesium stearate mixture (Fig. 2b) showed the respective characteristic bands of NTG at 1647, 1712, 2850-2953 (- $\mathrm{CH}_{2}$-cycloalkane) and $3300 \mathrm{~cm}^{-1}$. The results confirmed that there was no chemical interaction between NTG and magnesium stearate.

IST. - Lactose, polacrilin K, PVP and talc were used for the formulation of immediate release tablets of NTG as a diluent, superdisintegrant, binder and lubricant, respectively, based on the results of DSC thermograms and IR spectra. The drug-excipient mixtures were tested using the IST technique and the quantitative results are shown in Table II. 
However, as seen from Table II, there was less than $1 \%$ change in the drug concentration in IST samples after 3 weeks of storage under stressed conditions.

Moreover, when the HPLC chromatogram of the mixture of NTG and individual excipients was compared with that of pure NTG during the IST sample analysis, it was found that the retention time $(9.61 \mathrm{~min})$ and the shape of the NTG peak remained unchanged. Hence, it was concluded that NTG and the excipients used were compatible.

In case of the NTG-magnesium stearate mixture, no definite conclusion could be drawn based on the DSC results alone. However, the results of IST studies showed that the residual drug concentration was within the set limits and the characteristic bands of NTG were well preserved in the IR spectrum of NTG-magnesium strearate mixture, confirming their compatibility.

\section{Formulation development and stability study}

The tablets were evaluated after 3 months of storage under accelerated stability conditions $\left(40 \pm 2{ }^{\circ} \mathrm{C}\right.$ and $\left.75 \pm 5 \% \mathrm{RH}\right)$, the results of which are presented in Table IV. It is evident that the formulation is stable in terms of drug concentration, disintegration time (DT) and time required to release $85 \%(\mathrm{~m} / \mathrm{m})$ of the drug $\left(t_{85}\right)$. There was a change in the drug concentration of $<2 \%$, DT $<1 \mathrm{~s}$ and $t_{85}<0.75$ min after 3 months of storage under accelerated stability conditions, leading to the conclusion that the immediate release tablets of NTG were stable after storage under accelerated stability conditions.

Table IV. Evaluation of tablets after 3 months of storage at $40{ }^{\circ} \mathrm{C}$ and $75 \% \mathrm{RH}$

\begin{tabular}{lcccc}
\hline Parameter & $\begin{array}{c}\text { Control value } \\
\text { (initial) }\end{array}$ & 1 month & 2 months & 3 months \\
\hline Drug concentration remained $(\%)^{\mathrm{a}}$ & $99.6 \pm 2.4$ & $99.30 \pm 2.8$ & $98.9 \pm 3.4$ & $98.50 \pm 2.5$ \\
Hardness $\left(\mathrm{kg} \mathrm{cm}^{-2}\right)$ & $5.00 \pm 0.23$ & $5.00 \pm 1.32$ & $5.00 \pm 1.27$ & $5.00 \pm 1.63$ \\
DT $(\mathrm{s})^{\mathrm{a}}$ & $32.14 \pm 1.57$ & $36.21 \pm 1.88$ & $44.32 \pm 2.24$ & $46.11 \pm 2.33$ \\
$t_{85}(\mathrm{~min})^{\mathrm{a}}$ & $14.76 \pm 2.19$ & $15.43 \pm 1.26$ & $15.28 \pm 1.20$ & $15.27 \pm 1.82$ \\
\hline
\end{tabular}

$t_{85}$ time required to release $85 \%(\mathrm{~m} / \mathrm{m})$ of the drug.

a Mean \pm standard deviation $(n=3)$.

DT - disintegration time.

\section{CONCLUSIONS}

The results of the studies confirmed that DSC and IR could be used as rapid methods to evaluate the compatibility between NTG and excipients. However, the isothermal stress testing techniques after storage of the mixture of NTG and individual excipient should also be adopted in conjunction with DSC and IR studies to reach a definite conclusion. In the present study, the DSC analysis along with IR spectroscopy and HPLC analysis (for IST studies) were successfully employed to assess the compatibility of NTG with the excipients used in the development of immediate release tablet formulations. 
From the results of the DSC studies an interaction was suspected between NTG and magnesium stearate. However, based on the results of IR spectroscopy and IST study, the possibility of incompatibility between NTG and magnesium stearate was ruled out. Therefore, no definite evidence of interaction was observed between NTG and the excipients used in the development of in-house formulations of immediate release tablets of NTG. Based on probable compatibility of the excipients with NTG confirmed by the methods described above, formulations of immediate release tablets of NTG were developed using the excipients studied.

\section{REFERENCES}

1. R. K. Verma and S. Garg, Compatibility studies between isosorbide mononitrate and selected excipients used in the development of extended release formulations, J. Pharm. Biomed. Anal. 35 (2004) 449-458; DOI: 10.1016/j.jpba.2004.01.012.

2. E. C. V. Tonder, A. P. Lotter and S. A. Botha, Compatibility study between doxylamine succinate with other drugs and excipients using differential scanning calorimetry, Drug Dev. Ind. Pharm. 16 (1990) 2125-2133; DOI: 10.3109/03639049009023644.

3. S. Venkataram, M. Khohlokwane and S. H. Wallis, Differential scanning calorimetry as a quick scanning technique for solid state stability studies, Drug Dev. Ind. Pharm. 21 (1995) 847-855; DOI: 10.3109/03639049509026649.

4. R. Kandarapu, V. Grover, H. P. S. Chawla and S. Garg, Evaluation of compatibility of ketorolac tromethamine with selected polymers and common tablet excipients by thermal and isothermal stress testing, S.T.P. Pharm. Sci. 11 (2001) 449-457.

5. P. Mura, A. Manderioli, G. Bramanti, S. Furlanetto and S. Pinzauti, Utilization of differential scanning calorimetry as a screening technique to determine the compatibility of ketoprofen with excipients, Int. J. Pharm. 119 (1995) 71-79; DOI: 10.1016/0378-5173(94)00374.

6. P. Mura, M. T. Faucci, A. Manderioli, G. Bramanti and L. Ceccarelli, Compatibility study between ibuproxam and pharmaceutical excipients using differential scanning calorimetry, hot-stage microscopy and scanning electron microscopy, J. Pharm. Biomed. Anal. 18 (1998) 151-163; DOI: 10.1016/S0731-7085(98)00171.

7. S. A. Botha and A. P. Lotter, Compatibility study between naproxen and tablet excipients using differential scanning calorimetry, Drug Dev. Ind. Pharm. 16 (1990) 673-683; DOI: 10.3109/ 03639049009104410.

8. A. T. Serajuddin, A. B. Thakur, R. N. Ghoshal, M. G. Fakes, S. A. Ranadive, K. R. Morris and S. A. Varia, Selection of solid dosage form composition through drug-excipient compatibility testing, J. Pharm. Sci. 88 (1999) 696-704.

9. L. Gu, R. G. Strickley, L. H. Chi and Z. T. Chowhan, Drug-excipient incompatibility studies of the dipeptide angiotensin-converting enzyme inhibitor, moexipril hydrochloride: dry powder vs wet granulation, Pharm. Res. 7 (1990) 379-383.

10. J. F. McLeod, Clinical pharmacokinetics of nateglinide: a rapidly-absorbed, short-acting insulinotropic agent, Clin. Pharmacokinet. 43 (2004) 97-120.

11. M. E. Sangalli, P. Giunchedi, P. Colombo, U. Conte, A. Gazzaniga and A. La Manna, Cross-linked sodium carboxymethylcellulose as a carrier for dissolution rate improvement of drugs, Boll. Chim. Farm. 128 (1989) 242-247.

12. US Pharmacopoeia 30, National Formulary 25, USP Convention, Rockville 2007.

13. U.S. Department of Health and Human Services, Food and Drug Administration Center for Drug Evaluation and Research, Guidance for Industry: Dissolution Testing of Immediate Re- 
lease Solid Oral Dosage Forms, FDA CDER, Rockville (MD) 1997; Guidances/UCM070237; access date May 15, 2010.

14. J. W. Moore and H. H. Flanner, Mathematical comparison of dissolution profiles, Pharm. Technol. 20 (1996) 64-74.

15. A. Smith, Use of thermal analysis in predicting drug-excipient interactions, Anal. Proc. 19 (1982) 559-561.

16. T. Durig and A. R. Fassihi, Identification of stabilizing and destabilizing effects of excipient-drug interactions in solid dosage form design, Int. J. Pharm. 97 (1993) 161-170.

\section{$S A \check{Z} E T A K$}

\section{Ispitivanje kompatibilnosti nateglinida s pomoćnim tvarima u razvoju tableta nateglinida za trenutno oslobađanje}

NIHAR RANJAN PANI, LILA KANTA NATH i SUJATA ACHARYA

Koristeći termičke metode kao što su diferencijalna pretražna kalorimetrija (DSC) i infra-crvena spektrofotometrija (IR), te izotermička stres-testiranja (IST) ispitana je kompatibilnost nateglinida $\mathrm{s}$ izabranim ekscipiensima $\mathrm{u}$ razvoju tableta nateglinida za trenutno oslobađanje. Rezultati DSC ispitivanja pokazala su da magnezijev stearat stupa u određenu interakciju s nateglinidom. Međutim, IR i IST ispitivanja pokazuju da su svi upotrijebljeni ekscipiensi kompatibilni s nateglinidom. Optimirana formulacija bila je stabilna preko 3 mjeseca u testovima ubrzanog starenja $\left(40 \pm 2{ }^{\circ} \mathrm{C}\right.$ i $\left.75 \pm 5 \% \mathrm{RH}\right)$. Kompatibilnost ekscipiensa s nateglinidom uspješno je evaluirana koristeći kombinaciju termičke i IST metode, a formulacije razvijene koristeći kompatibilne ekscipiense bile su stabilne.

Ključne riječi: nateglinid, tableta za trenutno oslobađanje, inerakcije lijek-ekscipiens

Department of Pharmaceutical Technology, Gayatri College of Pharmacy, Sambalpur, Odisha-768200, India

Department of Pharmaceutical Sciences, Dibrugarh University, Dibrugarh Assam-786004, India

University Department of Pharmaceutical Sciences, Utkal University, Bhubaneswar, Orissa, India 